\title{
STANDARD BANK CREDIT AGREEMENT BASED ON THE VALUE OF JUSTICE
}

\author{
Sahal Afhami \\ Universitas Darul Ulum (UNDAR) Jombang \\ sahalafhamis3@gmail.com
}

\begin{abstract}
The treaty law is an open system with the principle of freedom of contract as stipulated in Article 1338 paragraph (1) of BW. The freedom provides an opportunity for all parties, including banks to make an agreement in the form of standaard. This standaard agreement is burdensome because there is no bargaining position between the community as a debtor customer with the bank as a creditor. However, such agreement continues in the banking practice. The purpose of this study is to find the factors influencing standaard bank credit agreement on the distribution of credit to the community based on the value of justice. This research uses normative juridical method, with primary-secondary data from the library research. Research aimed at finding the basics of law, rules of law, and legal doctrines, relating to a justice-based bank credit-based credit agreement. As a result, the bank credit agreement in the form of standaard is still not based on the value of justice because the content is determined unilaterally by the bank, where the debtor's customer does not have bargaining position on some form of agreement used by the bank; application credit agreement and bookkeeping requirements; cash bookkeeping requirements; Deposit book-entry application; application agreement of remittance. In addition, it still has delicacy on the bank credit agreements which are limited by the Banking Act and the Decree, Regulation and Circular of Bank of Indonesia. The legal provision generates the prudent principle of extending the credit to the community, which is famous for the 5 C's (Character, Capacity, Capital, Collateral, Condition). Meanwhile, the Bank Indonesia Regulation stipulates regulation relating to the regulations, prohibitions, institutions, guarantees, and execution of the guarantee objects.
\end{abstract}

Keywords: Agreement, Credit, Bank Standaard, Justice. 


\section{A. Introduction}

The treaty law provided in Book III, Chapter I-XVIII of the BW concerning Alliance of the Open System (Article 1338 paragraph (1) of the BW) states that the Agreement shall meet the requirements of the validity of the agreement (Article $1320 \mathrm{BW}$ ), and not contrary to the Law, Decency and public order (Article 1337 BW). With the principle of contracted freedom, someone is able to get into agreements with free forms and content. The free here is not freely free but free or freedom which is bounded by other liberties. It does not violate the laws and regulations.

Public legal awareness can be likened to an intermediary that can connect between legal subjects to enforce the law, or in other words that legal awareness is a bridge that can link the legal rules and the behavior of legal subjects. L. Friedmann mentions that a legal culture includes values, attitudes that affect the work of the law. ${ }^{1}$ Basically, Legal awareness is an assessment of what is regarded as a good law and / or a bad law. Assessment of the law is always addressed to the purpose of the law itself. Whether the law is fair or unjust, impartial or not, can protect or can not, and so on. Such things are always expected by society. ${ }^{2}$

The discipline in the society will be achieved because of the processes in it, which consists of relationships and contacts between members of the community. The higher the percentage of people who

${ }^{1}$ Esmi Waransih, 1983, Pembinaan Kesadaran Hukum Dalam Masalah-Masalah Hukum, Majalah Hukum Univrsitas Diponegoro, Semarang, page 9.

2 Soerjono Soekanto, 1987, Sosiologi Hukum Dalam Masyarakat, Rajawali Press, Jakarta, page 211. 
think or adhere the pattern the more orderly the legal awareness of the community. ${ }^{3}$ One of the form of agreement is a standaard form, which is an agreement made by one-sided and the other side merely accepts the contents. This agreement is laden with irregularities including bank credit agreements made in default by the bank, because the customer can not participate in determining the contents. They do not have bargaining position, they just accept it without being able to change it. However, in fact the debtor continues to accept it as a valid agreement (Article 1320 jo 1337 BW) and (Article 1338 paragraph (1) and paragraph (3) BW).

Research conducted by Sri Hartatik ${ }^{4}$ found that almost all customers are reluctant to express their difficulties. They tend to be passive and will only reveal the difficulty when the bank asks for it. Based on both studies, it is clear that the breach of contract occurs due to low awareness of the legal customer caused by low formal education and in turn, it causes the difficulties in the process of interpretation of the agreement substance. At the end, the customer fails to perceive the importance of meaning in the credit agreement.

The low awareness of the law in the form of non-compliance with the substance of the credit agreement of the bank shows that the existing legal culture in the client is still in the negative legal sense. Furthermore, to create a positive legal culture, namely the obedience of the agreement substance, required sufficient legal knowledge

${ }^{3}$ Satjipto Rahardjo, 1996, IImu Hukum, Aditya Bakti, Bandung, page 132

${ }^{4}$ Sri Hartatik, 2002, Pelaksanaan Perjanjian Kredit Dalam Kredit Pemilukan Rumah Dengan Jaminan Hak Tanggungan (Staudi Kasus Pada Bank Lippo Cabang Jakarta - Lipoo Plasa) Undip, Semarang, page 79 
making it easier in the process of understanding the agreement substance through interpretation. Failure to translate the symbolic meaning behind the substance of the agreement complicates the process of communicating between two sides. So, ultimately the default as a failure of communications is inevitable. The purpose of this study is to find the factors that influence the credit agreement of the bank in the form of standaard in lending to the community has not based on the value of justice. Besides that this research also explore the weaknesses in credit agreement of bank standaard in form of credit distribution to society at this time.

This research is a normative legal research (legal research), with normative juridical approach because the data source is literature study or data source commonly referred to as secondary legal materials. For the secondary-primary is in the form of legislation while the secondary-secondary is doctrines which are in books or research results, and the secondary-tertiary is in form of dictionaries or bibliographies.

\section{B. Discussion}

\section{Definition of Agreement}

Article 1313 BW provides the following definition of a treaty: "A covenant is an act which one or more people commit themselves to one or more others". The definition is translated from Article 1313 Burgerlijk Wet Boek (Dutch) which is: "Een overeenkomst is een 
handeling waarbij een of meer personen zich jegens een of meer andere verbinden".

According to the customary term in law juridische spraakgebruik) that what is meant by deed is any gewild regardless of whether the legal effect arising out of the action is expected or unexpected, so that zaakwaarneming and onrecht matige overheid daad can be called an agreement if the law maker puts 2 (two) actions into the second title and not into the third title. ${ }^{5}$

From the definition of an incomplete agreement, it is necessary to seek again from other sources of law, either from doctrine (communis oppinio doctorum) or the general opinion of the scholars (law) as well as from judges' decisions (jurisprudence) which is called as a factor assisting the formation of the law by van Apeldoorn. Meanwhile, according to Lemaire it is known as a determinant for the formation of the law. ${ }^{6}$ Hence, the result of the definition is clear. Setiawan provides the definition of the agreement as follows: ${ }^{7}$ "Covenant is a legal act in which one or more people bind themselves to one or others".

In the development of the era, the definition of the agreement can be said to be incomplete and too broad. Incomplete because only one unilateral agreement is formulated, such as a gift. Too broad because it may include matters related to marriage pledges, which fall within the legal of people and families. For example, grant and

${ }^{5}$ Soetojo Prawirohamidjojo, dan Marthalena Pohan, 1984, Hukum Perikatan, PT Bina Ilmu, Surabaya, page 84.

${ }^{6}$ Sudikno Mertokusumo, 1991, Mengenal Hukum, Liberty, Yogyakarta, page 94.

${ }^{7}$ R Setiawan, 1997, Pokok-Pokok Hukum Perikatan, Bumi Cipta, Bandung, page 49 
inheritance agreements may also include unlawful acts, although there is no an element of consent in it. The definition of the treaty must be sought in the doctrine and in the judges' decisions, which is called the factors that help the legislation by van Apeldoorn, and is called the determinant of the formation of the law by Lemaire, so that a clear definition can be produced. The definition of the treaty by Classical Theory: "The covenant is a legal act (rechtshandeling) based on an agreement to inflict a legal effect". This classical theory sees the agreement as a two-sided law. This means that agreements made by two or more parties see it as a legal act that has two legal consequences for both or more parties, so it can easily be cited that the agreement is an act of two sides (een tweezijdige rechtshandeling).

According to van Apeldoorn the act of law is an act which, by objective law, is attributed to the occurrence and disappearance of a subjective right as a result of that act, because the objective law presupposes that such a result is desired by the person acting. ${ }^{8}$

The classical theory sees in reverse, the agreement is seen as one legal act that actually contains two legal acts, i.e.: offer and acceptance of the bid, so the offer and acceptance of the bid are not seen as legal acts which stand alone to give an achievement. There is a gaffe in this classical theory because the agreement made by the two parties is considered as one legal act, whereas in theory and practice the agreement always made by involving two or more parties, while one party do its own legal acts, and the other party also do their own legal acts, so there are two legal actions. From both legal acts,

${ }^{8}$ Van Apeldorn L.J, 1981, Pengantar Ilmu Hukum, Pradnya Paramita, Jakarta, page. 226. 
there is one legal consequence that binding both parties. Therefore, the definition of agreement should search on contemporary theory.

The contemporary theory gives the definition of agreement as follow: "Agreement is a legal relationship (rechtsverhouding) between two or more parties based on an agree word to cause a legal effect ". Called as a legal relationship because it contains two legal acts, the legal acts of one party and the legal acts of the other party. Both of the legal acts have one legal consequence or can be said that the agreement is two legal acts which contain one (twee eenzijdige rechtshandelingen).

Then Van Apeldoorn stated that legal act consists of the unilateral legal act and two parties legal act. The unilateral legal act is an action of sufficient will statements by one individual to cause a legal consequence. While two parties legal act is a legal act which needs a conformity will statement from two people or more. ${ }^{9}$

\section{The Valid Requirement of Agreement.}

The valid requirement of agreement explained on article 1320 BW: ${ }^{10}$

1. Agree to those who commit themselves or agree;

2. Skill to make an agreement;

3. A certain thing;

4. A legal cause.

The first two requirements called subjective requirements because it is the subject of the agreement, while the second two requirement called objective requirement because it is the object of the agreement.

\footnotetext{
${ }^{9}$ van Apeldoorn, 1981, Op.Cit., page 227.

${ }^{10}$ Subekti, 1985, Civil Code, PT Intermasa Bandung, page 339.
} 
Without the fulfillment of one subjective condition, the agreement may be canceled (vernietigbaarheid), whereas by not fulfilling of one objective condition, the agreement is null and void (nietigbaarheid). ${ }^{11}$

Agree is a conformity between will and will statement not just conformity. It means that will is the real will not will as declared, this will be the will as declared, means than an agreed statement of will (overeenkomstemende wwilsverklaring) between parties. So, the agreement is not only the conformity between the will of those who promise but also includes the will and the declaration of will (w/sovereenkomstemming) it must be appropriate so the defective will cannot happen (wisgebrek). If the defective of will happened, it is not a defective agreement but the will itself which defect in the sense of the conditions of the occurrence, so that the agreement is held still, but can be annulled by filing a lawsuit of cancellation to court because it cannot be unilaterally canceled.

Eggen stated: An honorable person will keep its promises. Grotius stated: Promise is binding (pacta sunt servanda), we have to fulfill the promise (premissorum implendorum). ${ }^{12}$ If the defective of will happened, it is not the agreement that defect but the defect of the will itself in term of the condition occurrence, so the agreement still be held, but the cancellation can be requested to the judge by filing a lawsuit for agreement cancellation because the agreement can't be canceled unilaterally. ${ }^{13}$

${ }^{11}$ Subekti, 1979, Legal Agreement, PT Intermasa Bandung, page. 17-20.

12 Mariam Darus Badrulzaman, 1991, Agreement of Credit Bank, PT Citra Aditya Bakti, Bandung, page. 109.

${ }^{13}$ Sudikno Mertokusumo, 1991, Introduction of Law, Liberty, Yogyakarta, page. 59. 
The defective will is the will that occurs due to mistake (dwaling), force (dwang), fraud (bedrog) as required by article 1321 BW, also occurs due to the abuse of circumstances (Eg, misbruik van omstandigheden), both due to economic and psychological excellence, as the Supreme Court of Indonesia Decree Number 1904/K/Sip/1982, January 28,1984 about the cancellation of engagement and the Supreme Court of Indonesia Decree Number 3431/K/Pdt/1985, March 4, 1987 about the Borrowing Money Interest and Collateral Goods which in contrary with Rule and Justice. The basic of the cancellation in terms of: 14

- Special Circumstance (bijzondere omstandigheden);

- A real circumstance (kenbaarheid):

- Abuse (misbruik);

- Causal relation (causal verbaand);

\section{Standard Agreement}

As the adoption of an open system and the freedom of contract in the agreement (Article 1338 paragraph (1) of the BW), and (Circular of the Financial Services Authority Number 13/SEOJK.07/2014 about Standard Agreement), the agreement develop significantly including standard agreement. The characteristic of this standard agreement is the form and content are set unilaterally by the stronger parties, both economically and psychologically, in this case is, the bank as the creditor. While the customer as the debtor does not participate to determine the contents of the agreement but receives it because driven by necessity, the debtor is forced to accept the agreement.

\footnotetext{
${ }^{14}$ Nieuwenhuis in Henry P Panggabean, 1992, The Abuse of Circumstance (Misbruik van Omstandigheden) as One of Reason (new) to Cancel the Agreement (As a Legal Development in Indonesia), Liberty, Yogyakarta, page. 40.
} 
Standard agreement is the agreement that almost of its clauses have been standardized by the user (in the banking transaction is the bank concerned) and the other party (in the banking transaction is the bank customer) basically has no opportunity to negotiate or request a change. ${ }^{15}$

Standard Agreement contains a clause about exoneration term, which is a requirement that becomes a burden on consumer and/or entrepreneur responsibility. This exoneration clause can be used in the implementation of agreement as long as that agreement is conducted with a good intention.

Article 1338 paragraph (1) BW which give a freedom to anyone make an agreement with independent form and content as long as it is not in contrary to law, morals, and public order, and the agreement made is valid as the law for those who make it. That agreement according to BW really has a binding power. That agreement can be seen as preliminary agreement and fully legitimate. ${ }^{16}$

Standard Agreement as mentioned above contains weakness due to the requirements which unilaterally determined and the other party is forced to accept the situation because of its weak position. ${ }^{17}$

\section{Agreement of Credit Bank}

According to Subekti ${ }^{18}$ an agreement is an event which a person promises to others or where the two men promise to do one thing. Same as sale and purchase, lease, and trade agreement. The terms of

${ }^{15}$ Sutan Remy Sjahdeini, 1997, Syndication Credit of the Forming Process and Legal Aspect, Pustaka Utama Grafiti, Jakarta, page. 3.

${ }^{16}$ Vollmar, H.F.A., 1980, Legal and Civil Law, Section A, Translation Sri Soedewi Maschun Sofwaneksi Civil Law, Law Faculty of Gadjah Mada University, Yogyakarta, page. 7.

17 Mariam Darus Badrulzaman, 1991, Agreement of Credit Bank, PT Citra Aditya Bakti, Bandung, page. 37-38.

${ }^{18}$ R. Subekti, 1979, Loan Legal, Edt. IX, Pradnya Paramita, Jakarta, Page. 1. 
the credit agreement are found in the Government Instruction, which is addressed to the public of the bank, then issued Circular Letter by Bank Indonesia Number 2/539/UPK/Pemb. On 8 October 1966 in order to grant any kind of credits, the bank is obligated to use contract of agreement credit. ${ }^{19}$

Agreement of credit bank based on the term contained in: 1. Bank Indonesia Circular Letter (SEBI) Number 02/539/UPK/Pemb. 8 October 1966 about the instruction to the bank in order to grant the credit have to use "Contract of Agreement Credit," and 2. Bank Indonesia Letter (SBI) Number 03/1093/UPK/KPD, 29 December 1970 aimed at Foreign Exchange Banks throughout Indonesia in granting credit have to use "Credit Agreement". From this instruction then develop into "Agreement of Credit Bank"

This agreement must be written. According to Cabinet Presidium Instruction Number. 115/EK/IN/10/1996, 10 October 1996, banks are prohibited to grant credit "without clearly credit agreement." On Bank Indonesia Certificate Director Number 27/162/KEP/DIR and SEBI No. 27/17/UPB, 31 March 1995, every credit must be approved and agreed upon setting on "Written Credit Agreement." The credit agreement made in the form of notary certificates or authentic deeds are usually used for granting the large amounts of credit with medium or long term, such as investment loans, working capital loans, syndicated loans (credit extended by more than one creditor or more than one bank). ${ }^{20}$

The purpose of bank credit agreement must be written so that the agreement has legal certainty, no matter if it is made of the arms

\footnotetext{
${ }^{19}$ Mariam Darus Badrul Zaman, 1991, Op.Cit., page. 21.

${ }^{20}$ Sutarno, 2003, The Legal Aspect of Credit on Bank, Alfabeta CV. Bandung, page. 101.
} 
(Article $1874 \mathrm{BW}$ ), or made by or before a Notary called authentic deed / Article notarized (Article 1868 BW).

Abolishment of the credit aagreement. Article $1381 \mathrm{BW}$ about the abolishment of engagement applicable to the bank credit agreement, which is due: ${ }^{21}$

- Payment

- Subrogation (article $1382 \mathrm{BW}$ )

- Debt Update (Novation) (Article 1413 BW)

- Debt Encounter (Compensation) (Article 1425 BW) Credit Agreement Guarantee

- Decree of the Board of Directors of BI. 23/69 / KEP / DIR dated February 28, 1991, the bank's confidence in the ability of debtors to repay credit

- Articles 1131 - 1132 BW

- Article 8 of Law no. 7 year 1992 Jo. UU no. 10 of 1998 concerning Banking

- Article 24 paragraph (1) of Law no. 14 of 1967 concerning the old Banking that commercial banks do not provide unsecured loans

Warranties include:

- Personal Guarantee Article 1820 BW

- Material guarantee:

. Mortgages (Article 1162 BW)

. Mortgage right

. Pawn

. Fiduciary

${ }^{21}$ Mariam Darus Badrulzaman, et al, 2001, Op.Cit, page. 279. 


\section{FACTORS AFFECTING THE BANK CREDIT AGREEMENT FOR THE STANDARD FORM WHICH BASED ON THE VALUE OF JUSTICE}

In order to implement the internal control system, banks are required to have policies, procedures and organizational tools that have separation of functions. One of the internal control systems that must be owned by the bank is the internal control system in the credit, as outlined in the Bank Credit Policy Guidelines (PKP). Policy on credit to avoid policies regarding the credit to avoid, among others, include credit for speculative purposes; Credit provided without sufficient financial information; Insufficient financial information is exempted from credit to micro-businesses as long as it has obtained confidence in the debtor. Credits that require special skills not owned by banks; and loans to troubled debtors and/or debtors who have credit with collectability of Loss to other banks.

Principles of lending by bank and credits assessment aspects to avoid potential losses of some Banks in providing credit that is guided by the principle of credit trust and prudent belief in the ability and the debtor ability to pay off its debt. However, banker realizes that credit which is given have a high risk so that it is guided by Believe and Prudent's credit principle only to reduce the risk. Although some banks have taken intensive efforts with caution, yet even so still happen in the reality of bad credit.

Legal relation between the bank and the customer or another bank service users is a contractual relationship which based on a contract or agreement that agreed by both of side. The principle of freedom of contract means that parties are free to make any agreement 
in their free form and content. Freedom is not absolute because there are limitations that should not be passed, that is not to be contrary to the law, public order and decency.

According to a research, it reveals that factors, which cause bad credit, can divide into internal factors and external factors.

Internal factor is a factor that contained within the bank, example:

1. Inaccurate analysis

2. Influence of Bank owners in credit decisions;

3. The quality of bank management.

Instead of factors above, before approving loans, it must assess the debtor with an analysis known as C-5 as follows:

1. Character;

2. Capacity;

3. Capital;

4. Collateral;

5. Condition.

Instead of the internal factors above, there are external factors that cause bad credits namely:

1. The institution of guarantee that is not ideal, namely in the form of mortgages or fiduciary;

2. The terms of the validity of the credit agreement are not based on applicable legislation. Neither the subjective requirement nor the qualified objective.

3. Always on the basis of contractual standards contrary to legislation adversely affecting the debtor. So that the debtor cannot implement the agreement or the contract. 
If the internal factors and external factors abandoned by the bank, it will happen the bad credit. There are few aspects of credit assessment used by the Bank in order to avoid potential losses, among others are:

1. Character of prospective customer

2. Belief (feeling)

3. Certain ethnic or race (half of certain bank)

4. Ability to restore, by looking at financial flows (indicator by looking at the diary) (repayment capacity)

5. Cash flow should be positive (see merchandise circulation), view income (for consumer credit), and regular reference of customer's work.

6. Collateral (guarantee).

In the case of corporate credit (corporate credit), the certainty of who is legally authorized to borrow funds can be seen in the deed of establishment (and its deeds of amendment), as well as the company's articles of association and articles of association. ${ }^{21}$

Some of the causes of the defect of the will in the agreement, among others $^{22}$ :

1. errors or apostasy (dwaling)

2. coercion (dwang)

3. deception (bedrog), and the provisions of jurisprudence included in the category of disability will:

4. undue influence

The causes mentioned above are the trigger of the deviation of the principle of good faith. In relation to the standard credit agreement of the bank, in this case take the example: undue influence, related to the legal relationship between creditors or banks with creditors or customers because between both parties there is a gap that is economically and psychologically, where economically and 
psychologically the bank as a party superior to the customer. Furthermore, there may be abuse of circumstances, because the second party is mostly the party in need.

The bank may act arbitrarily imposes a responsibility to the customer beyond its capacity because the agreement has been written in the standard agreement, it could be a person receiving it because the customer is a party in need. This action can be classified as a form of deviation to the principle of good faith. This attitude of neglect does not mean there is no consequence at all because the principle is a legal act; it will have legal consequences as well. The weaknesses of bank credit agreements in the form of a standard are currently regulated in Article 1 point 11 of Law Number 10 Year 1998 concerning Banking provides the definition of credit, namely: "Provision of money or claims that can be ${ }^{22}$ Equalized, based on loan agreement or agreement between the bank and the other party requiring the borrower to repay the debt after a certain period of time with the giving of interest ".

The condition and characteristics of the national banking assets at present and in the future will still be affected by credit risk, which if not effectively managed will potentially disrupt the business continuity of the bank. Ineffective credit risk management, among others, is caused by weaknesses in the implementation of policies and procedures for the provision of funds, including the determination of quality, weaknesses in managing the asset portfolio of banks, and weakness in anticipating changes in external factors that affect the quality of provision of funds.

2222 Siswanto Sutojo, 2008, Analisa Kredit Bank Umum. Konsep Dan Teknik, Damar Mulia Pustaka, Jakarta, page 73.

22 article 1321 KUH Perdata 


\section{Conclusion}

It summed up that bank credit in the form of standard is not based on the value of justice because its content is determined unilaterally by the bank. on the other hand, the debtor's customer does not have bargaining position on some form of agreement used by the bank, application credit agreement and the conditions of the account of the application agreement and terms Savings bookkeeping, application agreement of time deposit accounts certificate of deposit, Transfer Application Agreement. The credit agreement of this Bank contains a clause, and almost all clauses are standardized, only a few that have not, for example, concerning the type, price, quantity, place, time and some specific specifics of the object being contracted. If this is analyzed with the theory of justice, although fair criteria should not be the same (Ius Commutativa), different is fair (Ius Distributiva), but bargaining position in the agreement is necessary because it is one of the conditions of validity of the agreement.

While the weaknesses of credit agreements Banks are limited by the provisions of the Act (Banking Act) and the provisions of Bank Indonesia (Decree, Regulation and Circular Bank Indonesia). The provisions of the Act resulted to the prudent principle of extending credit to the public, which is famous for the 5 C's (Character, Capacity, Capital, Collateral, and Condition). Meanwhile, the Bank Indonesia Regulation stipulates regulations relating to regulations, prohibitions, institutions, guarantees, execution of guarantee goods.

Bank credit agreements should be made in writing between the creditor of the bank and the debtor's customer (not a stand-alone arrangement prepared unilaterally by the bank). Either made directly 
by either of them, or through their respective representatives (Lawyers) and signed in front of a notary or signed in notary offices, whose contents are contained in clauses agreed upon by way of deliberation.

\section{REFERENCES}

Esmi Waransih. 1983. Pembinaan Kesadaran Hukum Dalam Masalah-Masalah Hukum. Majalah Hukum Univrsitas Diponegoro. Semarang.

Mariam Darus Badrul Zaman. 1991. Perjanjian Kredi Bank. PT Citra Aditya Bakti, Bandung.

Nieuwenhuis, dalam Henry P Panggabean. 1992. Penyalahgunaan Keadaan

(Misbruik van Omstandigheden) sebagai Salah Satu Alasan (Baru)

Untuk Pembatalan Perjanjian (Sebagai Perkembangan Hukum Di

Indonesia). Liberty. Yogyakarta.

R Setiawan. 1997. Pokok-Pokok Hukum Perikatan. Bumi Cipta. Bandung.

R. Subekti. 1979. Hukum Pinjaman, Cet. IX, Pradnya Paramita. Jakarta.

Satjipto Rahardjo. 1996. Ilmu Hukum. Aditya Bakti. Bandung.

Siswanto Sutojo, 2008, Analisa Kredit Bank Umum. Konsep Dan Teknik, Jakarta, Damar Mulia Pustaka.

Soerjono Soekanto, 1987, Sosiologi Hukum Dalam Masyarakat, Rajawali Press, Jakarta.

Soetojo Prawirohamidjojo dan Marthalena Pohan. 1984, Hukum Perikatan, PT Bina Ilmu. Surabaya.

Sri Hartatik, 2002, Pelaksanaan Perjanjian Kredit Dalam Kredit Pemilukan Rumah Dengan Jaminan Hak Tanggungan (Staudi Kasus Pada Bank Lippo Cabang Jakarta - Lipoo Plasa) Undip, Semarang.

Subekti. 1979. Hukum Perjanjian. PT Intermasa, Bandung. . 1985. Kitab Undang-Undang Hukum Perdata. PT Intermasa.

Bandung.

Sudikno Mertokusumo. 1991. Mengenal Hukum. Liberty. Yogyakarta.

Sutan Remy Sjahdeini, 1997, Kredit Sindikasi Proses Pembentukan dan Aspek Hukum, Pustaka Utama Grafiti. Jakarta.

Sutarno. 2003. Aspek-Aspek Hukum Perkreditan pada Bank. Alfabeta CV. Bandung.

Van Apeldorn L.J. 1981. Pengantar IImu Hukum. Pradnya Paramita. Jakarta. 
Vollmar, H.F.A. 1980. Hukum Perdata Hukum Perutangan. Bagian A. Terjemahan Sri Soedewi Maschun Sofwaneksi Hukum Perdata. Fakultas Hukum Universitas Gadjah Mada. Yogyakarta. 